\title{
MANAJEMEN KAMPANYE PUBLIC RELATIONS DALAM SOSIALISASI PROGRAM TANGGAP COVID-19
}

\author{
Muhammad Saifulloh dan Muhammad Fikri Lazuardi \\ Universitas Prof. Dr. Moestopo (Beragama), Jakarta - Indonesia \\ h.m.syaefullah@dsn.moestopo.ac.id
}

\begin{abstract}
This research focuses on the activities of the PT Pelabuhan Tanjung Priok Public Relations Campaign on Covid-19 Response in the Tanjung Priok Port Area. The purpose of this study was to determine the planning of the Covid-19 Response Campaign carried out by the Public Relations of PT Pelabuhan Tanjung Priok and what media were used in the campaign process. The theory used in this research is the 4 Steps Of Public Relations from Cutlip and also the concept of 10 Stages Of Campaign Planning. The research approach uses descriptive qualitative with a constructivist paradigm. Data collection in this study was carried out by means of observation and in-depth interviews with informants who were involved in the process of implementing the Covid-19 Response Campaign with the object of PT Pelabuhan Tanjung Priok. The results of research from the Covid19 Response Campaign carried out several stages in a comprehensive manner by forming a Covid Management Team together with the K3L and HR divisions. Considering the situation during the pandemic which limited activities outside the home, the Covid-19 Response Campaign was carried out by utilizing digital media such as Websites, Social Media, and the company's main internal channel, namely E-Office.
\end{abstract}

Keywords: campaign; response to Covid-19; PT. Tanjung Priok port

\begin{abstract}
Abstrak
Penelitian ini memfokuskan kepada kegiatan Kampanye Public Relations PT Pelabuhan Tanjung Priok tentang Tanggap Covid-19 di Area Pelabuhan Tanjung Priok. Tujuan dari penelitian ini adalah untuk mengetahui perencanaan kegiatan Kampanye Tanggap Covid-19 yang dilakukan oleh Humas PT Pelabuhan Tanjung Priok dan media apa saja yang digunakan dalam proses kampanye tersebut. Teori yang digunakan dalam penelitian ini yaitu 4 Steps Of Public Relations dari Cutlip dan juga konsep 10 Stages Of Campaign Planning. Adapun pendekatan penelitian ini menggunakan Deskriptif Kualitatif dengan paradigma Konstruktivis. Pengumpulan data dalam penelitian ini dilakukan dengan cara Observasi dan Wawancara Mendalam dengan Informan yang terlibah dalam proses pelaksanaan kegiatan Kampanye Tanggap Covid-19 dengan objek PT Pelabuhan Tanjung Priok. Hasil penelitian dari Kampanye Tanggap Covid-19 dilakukan beberapa tahapan secara komprehensif dengan membentuk Tim Penanganan Covid bersama dengan divisi K3L dan SDM. Menimbang keadaan saat pandemi yang membatasi kegiatan di luar rumah, maka Kampanye Tanggap Covid-19 ini dilakukan dengan memanfaatkan media digital seperti Website, Media Sosial, dan kanal utama internal perusahaan yaitu E-Office.
\end{abstract}

Kata Kunci : kampanye; tanggap Covid-19; PT. Pelabuhan Tanjung Priok

\section{PENDAHULUAN}

Hubungan Masayaraka adalah fungsi manajemen secara khusus yang mendukung terbentuknya saling pengertian dalam komunikasi, pemahaman, penerimaan dan kerja sama antara organisasi dengan berbagai publiknya dalam (Soemirat \& Ardianto, 2012:14).

Dalam ilmu Kehumasan, Humas memiliki landasan untuk membuat strategi 
yang terintegrasi dari fungsi dan peran Humas. Strategi tersebut dapat digunakan untuk membantu menyelesaikan persoalan yang sedang dihadapi perusahaan. Oleh karena itu, strategi Kampanye Public Relations (Humas) merupakan suatu hal penting yang harus dimiliki Humas guna membantu kinerja mereka didalam suatu perusahaan yang dapat digunakan ketika berhadapan dengan sebuah fenomena maupun masalah.

The British Institute of Public Relations menyatakan bahwa aktivitas Humas adalah mengelola komunikasi antara organisasi, dan publiknya dan Public Relations adalah memikirkan, merencanakan dan mencurahkan daya untuk membangun dan menjaga saling pengertian antara organisasi dan publiknya (Ruslan, 2010:15) .

Fenomena pandemi Covid-19 yang terjadi diawal tahun 2020 berdampak pada berbagai sektor usaha yang ada di Indonesia. Pelabuhan merupakan 11 sektor penting yang mengharuskan dilakukannya optimalisasi kinerja perusahaan, oleh karena itu Humas PT Pelabuhan Tanjung Priok turut berperan aktif dalam transformasi kinerja dan tata kelola perusahaan di masa pandemi. Humas dituntut untuk mampu berperan sebagai Problem Solving yang mana peran Humas tersebut merupakan pihak yang dapat memecahkan suatu permasalahan yang sedang dihadapi melalui strategi kehumasan yang dimiliki oleh organisasi atau perusahaan. Pentingnya peran Humas dalam suatu organisasi maupun perusahaan ini menjadikan Humas sebagai pihak yang mampu menyusun strategi komunikasi yang salah satunya berupa Kampanye Public Relations. karena kampanye Public Relations dipercaya mampu memperbaiki citra suatu perusahaan dan efektif digunakan sebagai strategi PR (Kaligis, 2020)

Permasalahan utama yang dihadapi Humas PT Pelabuhan Tanjung Priok saat ini adalah Selain maslaah komunikasi, Komunikasi yang memainkan peran penting dalam menyampaikan informasi secara langsung atau tidak langsung (Hogg, 2018: 111).bergesernya atau berubahnya sistem dan pola kerja perusahaan yang merupakan imbas dari fenomena pandemi Covid-19 yang sedang terjadi. Humas wajib dibekali dengan kompetensi dasar Kehumasan yang maskimal guna merencanakan strategi, kampanye, hingga merangkul beberapa divisi dan pihak yang berkepentingan untuk mampu menghadapi fenomena Covid-19 ini. Yang dimana didalamnya kampanye tersebut terdiri dari tahap riset serta perencanaan strategis (Amalia, 2012). Langkah Humas yang tepat dan optimal diharap dapat meminimalisir penyebaran virus serta memecahkan berbagai macam persoalan yang disebabkan oleh virus Covid-19. proses mendefinisikan masalah, perencanaan dan pemrograman, mengambil tindakan dan komunikasi hingga kegiatan mengevaluasi (Khoerunnisa, 2018). Dengan demikian, penelitian ini menitik beratkan pada perencanaan dan implementasi kampanye Humas yang dilakukan PT Pelabuhan Tanjung Priok tentang Tanggap Covid-19.

Di dalam sektor kepelabuhanan, wabah virus Covid-19 telah membatalkan 544 pelayaran dari total sekitar 1.300 pelayaran rute intra-Asia dalam jangka waktu 30 hari sejak perayaan Imlek 25 Januari 2020. PT Pelabuhan Indonesia II (IPC) memperkirakan kunjungan kapal dan aktivitas kargo pada bulan Februari 2020 berkurang hingga 5\% seiring dengan penyebaran virus Covid-19. Berdasarkan kutipan wawancara Media Kontan dengan General Manager IPC Tanjung Priok, Suparjo Kasnadi yang menyatakan bahwa adanya dampak dari penurunan kinerja. Terdapat pengurangan arus kapal sejak dua bulan terakhir untuk pergerakan dari dan ke Asia walaupun tergolong tidak terlalu signifikan. Saat ini sudah dilakukan pengurangan arus barang terutama untuk internasional, terutama di Pelabuhan Tanjung Priok yang merupakan pelabuhan terbesar. Virus Covid-19 berdampak terhadap penurunan arus barang karena sejalan dengan penurunan jumlah produksi dan distribusi, namun diharapkan dampaknya tidak akan banyak mempengaruhi kinerja pendapatan karena tingkat perdagangan domestik antar pulau di Indonesia dapat terjaga. PT Pelabuhan 
Indonesia II mengantisipasi dengan mulai meningkatkan distirbusi asrus barang dalam negeri antar pulau dan wilayah Indonesia Barat dan Timur yang sebelumnya memiiliki dominan orientasi terhadap aktivitas ekspor dan impor barang. Hal tersebut memastikan kegiatan kepelabuhanan seperti bongkar muat tetap berjalan.

Divisi Humas PT Pelabuhan Tanjung priok dengan serius mengkampanyekan beberapa program dan kegiatan guna menerapkan dan mensosialisasikan K3L (Kesehatan, Keselamatan Kerja Lingkungan). Kampanye public relations memiliki proses dan teknik komunikasi tertentu. Ruslan (2013,7174) Kampanye tersebut akan dilakukan beriringan dengan penelitan yang akan penulis teliti, sehingga penulis akan terus memperbaharui program-program yang telah atau akan dilaksanakan oleh bagian Humas PT Pelabuhan Tanjung Priok berkaitan dengan Tanggap Covid-19. Berdasarkan data yang peneliti peroleh pra penelitian, Humas PT. Pelabuhan Tanjung Priok telah berupaya mensosialisasikan kampanye Tanggap Covid19 melalui media internal seperti E-Office dan beberapa platform sosial media lainnya seperti Instagram, Twitter, dan juga Facebook.

Tujuan Penelitian untuk mengetahui perencanaan kegiatan kampanye Humas PT Pelabuhan Tanjung Priok Tentang Tanggap Covid-19 di Area Pelabuhan Tanjung Priok dan untuk mengetahui media kampanye apa saja yang digunakan oleh Humas PT Pelabuhan Tanjung Priok dalam mensosialisasikan Tanggap Covid-19. bagaimana kampanye tersebut digunakan oleh sebuah komunitas untuk mencapai tujuan organisasinya.( Chandra, 2014).

Untuk memperkuat penelitian ini digunakan referensi penelitian Ratnawati, (2017) Tujuan penelitiannya: Untuk mengetahui strategi kampanye yang diterapkan Public Relations dalam meningkatkan kesadaran masyarakat melakukan donor darah pada palang merah indonesia (PMI) Kota Makasar dengan menggunakan Teori Strategy Of Publicity \& Strategy Of Persuation.
Berikutnya, penelitian Drara Novia Dwi Astriani, (2012). Yang bertujuan untuk mengetahui manajemen kampanye Public relations PT. Djarum dalam menghadapi isu melalui kegiatan Factory Visit. Penelitian ini merupakan penelitian kualitatif dengan pendekatan deskriptif , dimana penulis menggunakan teori Corporate Campaign Teori dan Issue Life- Cycle Theory. Adapun perbedaaan dari kedua penelitian terdahulu dengan penelitian penulis, yaitu penulis menggunakan 4 Steps Of Public Relations dan 10 Stages Of Campaign Planning.

\section{METODOLOGI PENELITIAN}

Pada penelitian Kampanye Public Relations PT Pelabuhan Tanjung Priok tentang Tanggap Covid-19, penulis menggunakan pendekatan Kualitatif deskriptif. Creswell menyebutkan bahwa penelitian yang dibimbing dengan metode kualitatif adalah suatu proses penelitian yang diselenggarakan untuk memahami permasalahan manusia atau permasalahan sosial,dengan cara menciptakan gambaran yang menyeluruh serta kompleks melalui laporan berupa katakata,pandangan yang detail dari sumber informasi dan latar belakang yang alamiah (Gunawan, 2013:82-83)

Metode Kualitatif deskriptif ini memfokuskan pada observasi dan suasana alamiah. Peneliti terjun langsung kelapangan,bertindak sebagai pengamat. Membuat kategori perilaku,mengamati gejala dan mencatatnya dalam buku observasi. Sifat penelitian yang digunakan yaitu penelitian yang bersifat deskriptif dengan pendekatan kualitatif dimana data-data yang diperoleh nantinya tidak berupa angka tetapi berupa kata-kata (penjelasan). Penelitian deskriptif dimaksudkan untuk memberikan data seteliti mungkin tentang manusia,keadaan atau gejala-gejala lainhya. Berdasarkan paparan tentang penelitian ini menggunakan pendekatan Kualitatif deskriptif yang memiliki karakteristik sebagai berikut, Pertama, Peneliti memperoleh data melalui: hasil pengamatan peneliti dan hasil wawancara oleh peneliti terhdap orang-orang yang ada dilingkup 
penelitian. Kedua, Peneliti yang mengidentifikasi serta mendeskriptifkan suatu permasalahan dan mencari solusi permasalahan melalui pengamatan peneliti dan temuan peneliti dilapangan. (Basrowi dan Suwandi, 2008:21)

Penelitian bersifat deskriptif erat kaitannya dengan data kualitatif. Hal ini didasari pandangan bahwa dengan menggunakan jenis data penelitian kualitatif, peneliti diberi "Kesempatan untuk membuat interpretasi-interpretasi alternatif dalam menganalisis teks secara menyeluruh". Dalam penelitian ini, permasalahan akan dikaji menggunakan pemikiran dan analisis penerapan Kampanye Public Relations PT Pelabuhan Tanjung Priok tentang tanggap Covid-19 di area Pelabuhan Tanjung Priok.

\section{HASIL DAN PEMBAHASAN}

\section{Jenis Kampanye}

Membicarakan jenis-jenis kampanye pada prinsipnya adalah membicarakan motivasi yang melatarbelakangi diselenggarakannya sebuah program kampanye. Motivasi tersebut pada gilirannya akan menentukan kearah mana kampanye akan digerakan dan apa tujuan yang akan dicapai. Jadi secara inheren ada keterkaitan anatara motivasi dan tujuan kampanye.

Menurut Charles U. Larsonia telah membagi beberapa jenisjenis kampanye yang berkaitan dengan komunikasi,yaitu, Pertama, Product-Oriented Campaigns, Kegiatan dalam kampanye berorientasi pada produk,dan biasanya dilakukan dalam kegiatan komersial kampanye promosi pemasaan sutau peluncuran produk yang baru. Promosi pemasaran suatu peluncuran produk yang baru. Kedua, Candidate-Oriented Campaigns, Kegiatan kampanye berorientasi bagi calon (kandidat) untuk kepentingan kampanye politik (political campaigns). Serta kampanye komunikasi pemasaran dan periklanan atau menggunakan teknik kampanye PR dalam jangka waktu relatif pendek3-6 bulan dengan dukungan dana yang cukup besar (investasi) untuk pengeluaran periklanan komersial. Ketiga, Ideological $\mathrm{Or}$
Cause-Oriented Campaigns, Jenis kampanye ini berorientasi yang bertujuan bersifat khusus dan berdimensi perubahan sosial (Social Change Campaigns), misalnya kegiatan kampanye sosial bersifat khusus non kormesial. (Venus 2007:10-11).

\section{New Media}

New New Media merupakan sebuah media baru yang memberikan kontrol yang sama pada setiap pengguna mengenai kapan dan dimana para pengguna dapat mengakses konten yang telah disediakan oleh new new media yang bersifat teks, suara, dan konten audiovisual. New new media memberikan lebih banyak keuntungan daripada new media ataupun dibandingkan dengan media lama. Pada new media penggunanya harus menunggu konten yang akan diproduksi orang lain. Kelebihan dengan menggunakan new new media, pengguna dapat menciptakan konten sendiri tanpa harus menunggu orang lain untuk memproduksi konten dan mendaptkan tanggapan dari orang lain dengan waktu yang tidak terlalu lama (Levinson, 2013:5).

Disamping itu, unsur-unsur utama lainnya dari new new media adalah konsumen dapat berperan menjadi produser. New new media dapat dengan mudah dipraktekan hanya dengan satu orang yang bekerja sendirian, misalnya menulis blog atau merekam sebuah video dan dapat mengunggah video tersebut melalui Youtube. (Levinson, 2013:3)

Adapun karakteristik dari New New Media berdasarkan dalam buku Levinson (2013:3-5) adalah sebagai berikut : a) Setiap pengguna berguna berperan sebagai produsen, Karakteristik ini merupakan karakteristik yang mendasar dari new new media. Siapapun yang memiliki akun new new media dapat menjadi produsen pada akun pribadinya, selain itu pengguna dapat mengatur akun yang dimiliki sesuai dengan kebutuhan. Contohnya, pengguna yang memiliki blog dapat menulis tulisan dan diunggah pada blog milik pribadi, membaca blog milik orang lain dapat memberikan dan berbalas komentar; b).Mudah didapat dan tidak berbayar, Dengan new new 
media, pengguna dapat dengan mudah mendapatkan apa yang dicari tanpa harus membayarnya, pengguna dapat menikmati apa yang ada dalam new new media. Jika dengan media lama untuk dapat membaca surat kabar harus membelunya terlebih dahulu, dengan adanya new new media cukup membuka salah satu situs beritaonline dan akan mendapatkan informasi yang dibutuhkan. c).Kompetitif dan saling terhubung, New new media memiliki karakteristik bersaing dengan kompetitif dan dapat saling terhubung satu sama lain. Sebagai contohnya adalah jika menggunakan apilkasi Twitter, pengguna dapat mengatur setelan pada sambungan sehingga apa yang diunggah pengguna dapay disambungkan dengan aplikasi lain, seperti aplikasi Facebook; d) Dapat dijadikan lading berbisnis, New new media selain dapat digunakan sebagai mesin pencarian segala informasi, bias digunakan sebagai lading untuk berbisnis. New new media bekerja seperti tangan kanan atau kepercayaan penggunanya. Seiring dengan perkembangannya, kini new new media digunakan sebagai toko online atau online shop.

\section{Four Steps Public Relations}

Pertama, Fact Finding (Pengumpulan data dan informasi), Tahap pertama dari penelitian ini adalah Fact Finding (pengumpulan data dan informasi) dari publik internal dan stakeholder (pelanggan). Dalam fact finding ini yang menjadi masalah (Problem) adalah terjadinya fenomena pandemi Covid-19 yang berdampak pada kinerja operasional pelabuhan dan terjadi pergeseran sistem kerja menjadi sistem online atau daring (Dalam Jaringan).

Hal ini sebagaimana peneliti kutip dari penyataan informan pendukung ke-3 Wiyono, yaitu staff atau pegawai PT Pelabuhan Tanjung Priok, Pernyataan lainnya disampaikan oleh informan ke-2 Dhiyah selaku staff Humas PT Pelabuhan Tanjung priok, informan kunci ke-1 yaitu Ibu Amanda Maulina dan dua informan pendukung ke-2.

Dari ketiga penyataan informan kunci ke-1 yaitu Ibu Amanda Maulina dan dua informan pendukung ke-2 yaitu Dhiyah dan ke3 Wiyono maka dapat disimpulkan bahwa pernyataan tersebut memberikan gambaran tentang masalah yang terjadi saat pandemi Covid-19 yang menyebabkan bergesernya pola kerja dan tata kelola perusahaan yang perlu disosialisasikan atau dikampanyekan kepada internal perusahaan dan para stakeholder (pelanggan) terkait pencengahan serta penanggulangan virus Covid-19 dan juga kegiatan operasional perusahaan tetap berjalan normal meskipun dengan beberapa perubahan mekanisme didalamnya. Pihak perusahaan telah melakukan interaksi dan koordinasi serta menerima banyak masukan dan saran dari pihak-pihak yang kredibel dan berkepentingan guna optimalisasi kerja serta pencegahan virus Covid-19 yang sedang terjadi saat ini.

$$
\text { Kedua, Planning (Perencanaan). }
$$

Langkah selanjutnya dalam penelitian ini adalah peneliti akan memberikan pemaparan terkait dengan perencanaan Kampanye Tanggap Covid-19 di areal Pelabuhan Tanjung Priok. Adapun alasan dilakukannya perencanaan Kampanye Tanggap Covid-19 sebagaiamana telah dikemukakan oleh informan ke-1 Amanda Maulina selaku DVP Corporate Communications.

PT Pelabuhan Tanjung Priok telah melakukan perencanaan kampanye yang optimal dengan membentuk Tim Khusus Penanggulangan dan penanganan Covid-19 yang terdiri dari tiga divisi. Selain itu, Humas PT Pelabuhan Tanjung Priok taat mengukuti anjuran ataupun instruksi pemerintah seiring dengan perkembangan dari fenomena Covid19. Program dan perencanaan Kampanye PT Pelabuhan Tanjung Priok berjalan dengan baik, sehingga staff dan karyawan perusahaan mampu mendapatkan informasi yang diperlukan.

Ketiga, Action And Communication (Aksi dan Komunikasi), Peneliti melanjutkan penelitian ini ke tahap tiga yaitu terkait dengan strategi aksi dan komunikasi. Melalui tahap ini, peneliti dapat menggali lebih dalam dengan melakukan wawancara dengan informan untuk mendapatkan data yang dibutuhkan. 


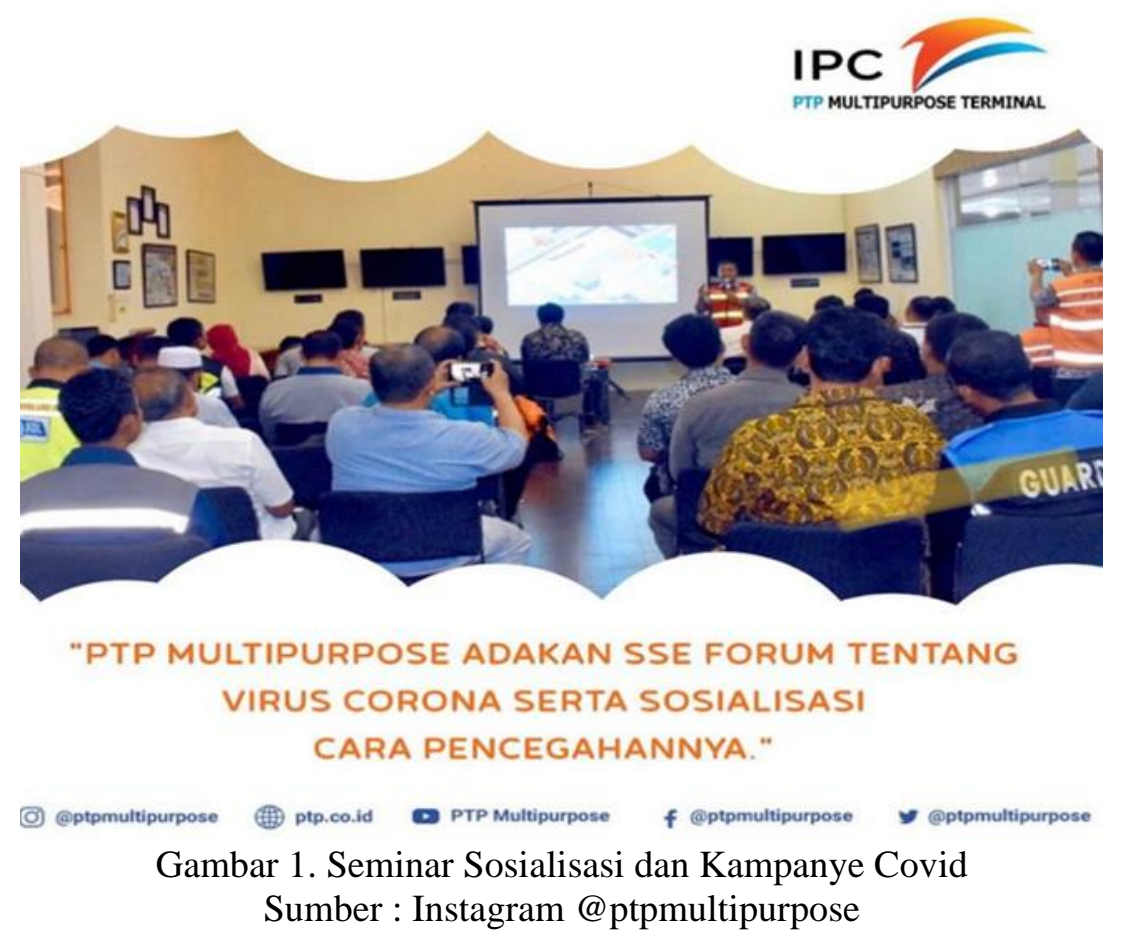

Strategi aksi dan komunikasi Humas PT Pelabuhan Tanjung Priok berjalan sejak awal mula munculnya virus Covid-19 di Indonesia dan sebelum ditetapkannya Covid-19 menjadi bencana nasional. Pada gambar 1 merupakan bentuk aksi dan komunikasi melalui sosialisasi dan kampanye yang dilakukan oleh pihak Humas PT Pelabuhan Tanjung Priok dengan tanggap dan disesuaikan dengan perkembangan keadaan saat ini, oleh karena itu ketika Covid19 ditetapkan menjadi bencana nasional maka segala bentuk sosialisasi dan kampanye dilakukan secara online atau daring (dalam jaringan).

Keempat, Evaluation (Evaluasi) Tahap selanjutnya yaitu implementasi program kampanye dan siapa yang bertanggung jawab untuk pengimplementasian setiap tindakan komunikasi. diharapkan kampanye ini mampu memberikan tindakan yang bersifat membangun serta menghasilkan perubahan positif kepada khalayak (Sugianto \& Sembiring, 2018). Untuk itu Humas PT Pelabuhan Tanjung Priok masih perlu melakukan evaluasi dalam kegiatan kampanyenya, terutama perihal ketepatan waktu yang direncanakan, Langkah-langkah strategis yang akan ditempuh yaitu pertama adalah strategi tindakan, yang kedua adalah strategi komunikasi. Dalam menyusun strategi komunikasi ada beberapa hal yang harus diperhatikan, adapun strategi tindakan yang dimaksud yaitu suatu perencanaan komunikasi dan pesan komunikasi yang dapat diimplementasikan sesuai dengan audience yang menjadi target sasaran komunikasi. Sedangkan yang menyangkut strategi komunikasi yaitu perencanaan komunikasi meliputi komunikator pesan, target sasaran dan feedback atau hasil.

Proses pengembangan tahap-tahap perencanaan suatu pelaksanaan program kegiatan kampanye Public Relations secara keseluruhan meliputi tujuan, publik sasaran dan pesan-pesan yang efektif, baik betujuan jangka panjang (strategi) maupun berbentuk secara micro (individual) dalam pelaksaan jangka pendek dengan tujuan khusus (taktik) dapat dilaksanakan secara bersama-sama melalui proses 10 tahapan atau rangkaian perencanaan kampanye secara logis. (Gregory, 2004:36).

Divisi Humas PT Pelabuhan Tanjung Priok menggunakan strategi Komunikasi Public Relations dalam melaksanakan kampanye Tanggap Covid-19. Adapun langkah awal mereka yaitu dengan melakukan riset 
terlebih dahulu tentang situasi dan fenomena pandemi Covid-19 yang terjadi saat ini serta dampak bagi kinerja operasional perusahaan. Kemudian berdasarkan fakta yang ditemukan di lapangan, Humas PT Pelabuhan Tanjung Priok mencari solusi yang dapat digunakan utntuk mengatasi situasi pandemi Covid-19 yang sedang terjadi. Pihak perusahaan juga merangkul stakeholder (pelanggan) dan beberapa pihak yang memiliki kredibilitas untuk berdiskusi dan berkoordinasi guna berjalannya program-program yang direncanakan.

Berdasarkan kutipan hasil wawancara dengan informan utama DVP Corporate Communications PT Pelabuhan Tanjung Priok, pelabuhan merupakan 11 sektor strategis sehingga menuntut perusahaan untuk melakukan optimalisasi kinerja di masa pandemi ini. Kampanye Tanggap Covid-19 yang dilakukan memiliki fokus utama yaitu untuk mengkampanyekan pencegahan dan penanggulangan virus Covid-19 serta memberikan informasi pelayanan yang tetap berjalan normal. Hasil wawancara berikutnya juga peneliti dapatkan dari informan pendukung ke-3 selaku staff PT Pelabuhan Tanjung Priok mengatakan bahwa diawal munculnya virus Covid-19 berdampak langsung terhadap pola kerja staff dan karyawan baik di kantor maupun di lapangan (operasional). Pihak Humas telah melakukan sosialisasi dan kampanye terkait penyesuaian pola kerja dan beberapa protokol kesehatan yang harus ditaati guna pencegahan dan penanggulangan virus Covid-19.

Sebelum melakukan sosialisasi dan kampanye, PT Pelabuhan Tanjung Priok secara khusus membentuk Tim Penanganan Covid-19 bersama dengan dua divisi lainnya yaitu divisi K3L dan divisi SDM. Pembentukan Tim Penanganan Covid-19 ini merupakan suatu bentuk upaya perencanaan yang terstruktur, sehingga masing-masing divisi memiliki tugas dan tanggung jawab masing-masing perihal Tanggap Covid-19. Perencanaan tersebut dimulai sejak awal merebaknya virus Covid-19 di Indonesia, Tim Penanganan Covid-19 melalui divisi Humas PT Pelabuhan Tanjung Priok giat melakukan sosialisasi dan kampanye dengan membuat Alur Komunikasi Pelaporan Covid-19 hingga sosialisasi New Normal yang akan segera dilakukan. Bentuk aksi komunikasi atau Communicating yang dilakukan oleh PT Pelabuhan Tanjung Priok yaitu dengan melakukan sosialisasi dan kampanye Tanggap Covid-19 melalui seminar langsung yang dilaksanakan sebelum Presiden Republik Indonesia, Joko Widodo menetapkan Covid-19 sebagai bencana nasional. Setelah itu, sosialisasi dan kampanye PT Pelabuhan Tanjung Priok beralih ke digital yang menggunakan media sosial dan website milik perusahan serta kanal khusus untuk internal pegawai/staff PT Pelabuhan Tanjung Priok (EOfifce) sebagai saluran kampanye.

Kemudian PT Pelabuhan Tanjung Priok secara komprehensif menggunakan 10 Tahap Perencanaan Kampanye dalam pelaksanaan program-program kampanye. Dimulai dengan melakukan analisis situasi maka PT Pelabuhan Tanjung Priok melakukan sosialisasi dan kampanye terkait pencegahan dan penanggulangan virus Covid-19 guna mencegah dan memutus rantai penyebaran virus Covid-19 khususnya di Area Pelabuhan Tanjung Priok. Analisis berikutnya berkitan dengan optimalisasi kinerja disaat pandemi, sehingga pihak Humas PT Pelabuhan Tanjung Priok mensosialisasikan serta mengkampanyekan pelayanan operasional yang tetap berjalan normal kepada stakeholder (pelanggan) dengan mentaati peraturan protokol kesehatan dari pemerintah. Adapun tujuan utama dari diselenggarakannya Kampanye Tanggap Covid-19 ini adalah untuk pencegahan dan penanggulangan Covid-19 dan pelayanan operasional yang tetap berjalan normal yang terkhusus bagi internal perusahaan dan juga stakeholder (pelanggan).

Pesan yang disampaikan berbentuk sebuah konten dengan dominasi grafis yang dimaksudkan agar audience lebih mudah dan cepat memahami isi pesan kampanye tersebut tanpa harus membaca keterangan mendalam. Bahasa yang digunakan juga tergolong 
sederhana agar terkesan lebih bersahabat dengan audience dan tidak bersifat formal seperti release. Humas PT Pelabuhan Tanjung Priok dengan giat mengkampanyekan Tanggap Covid-19 melalui media, media komunikasi adalah semua sarana yang dipergunakan untuk memproduksi, mereproduksi, mengolah, mendistribusikan atau menyebarkan dan menyampaikan informasi. Media komunikasi juga sangat berperan dalam kehidupan masyarakat. Secara sederhana, media komunikasi adalah pernanan dalam penyampaian informasi dari komunikator kepada komunikan yang bertujuan untuk efisiensi penyebaran informasi atau pesan tersebut (Suryanto, 2015).

Mengingat kondisi saat pandemi yang membatasi kegiatan di luar rumah maka Humas PT Pelabuhan Tanjung Priok menggunakan media digital sebagai saluran alternatif utama dalam pelaksanaan sosialisasi dan kampanye Tanggap Covid-19. Media sosial utama yang digunakan adalah Facebook dan Instagram, mengingat kedua media sosial tersebut merupakan platform terbesar dan mendominasi saat ini sehingga dapat menjangkau banyak audience. Media lain yang digunakan adalah kanal khusus internal perusahaan yaitu EOffice. Kanal ini menjadi media utama dalam kegiatan pekerjaan sehingga dapat dimanfaatkan sebagai saluran ataupun media kampanye. Pihak Humas PT Pelabuhan Tanjung Priok juga telah menyiapkan Timeline kegiatan program kampanye agar berjalan lebih efektif, meskipun terdapat sedikit evaluasi didalam pelaksanaannya.

\section{Tahap Perencanaan Kampanye Analysis (Analisis Situasi)}

Divisi Humas PT Pelabuhan Tanjung

Priok telah melakukan Analisa situasi sejak awal munculnya virus Covid-19 di Indonesia. Pihak Humas perusahaan pun turut aktif mengikuti perkembangan dan instruksi dari pihak holding (IPC/PT Pelabuhan Indonesia II) maupun dari pemerintah. Analisis ini dilakukan untuk mengidentifikasi permasalahan yang akan menjadi dasar dari program Public
Relations, sehingga Humas PT Pelabuhan Tanjung Priok menerapkan beberapa kebijakan yang disesuaikan dengan perkembang situasi terkini untuk menjamin kinerja operasional yang tetap berjalan normal tanpa mengabaikan protokol kesehatan yang sudah ditetapkan.

\section{Objectives (Tujuan)}

Adapun tujuan dari dilakukannya kampanye dan sosialisasi Tanggap Covid-19 PT Pelabuhan Tanjung Priok ialah untuk mencegah serta menanggulangi penyebaran virus Covid-19 khususnya di areal pelabuhan Tanjung Priok. Tujuan berikutnya adalah untuk menjaga kepercayaan pelanggan bahwa kinerja dan komunikasi antara perusahaan tetap berjalan dengan baik dan memperhatikan prosedur dan protokol kesehatan yang telah ditetapkan.

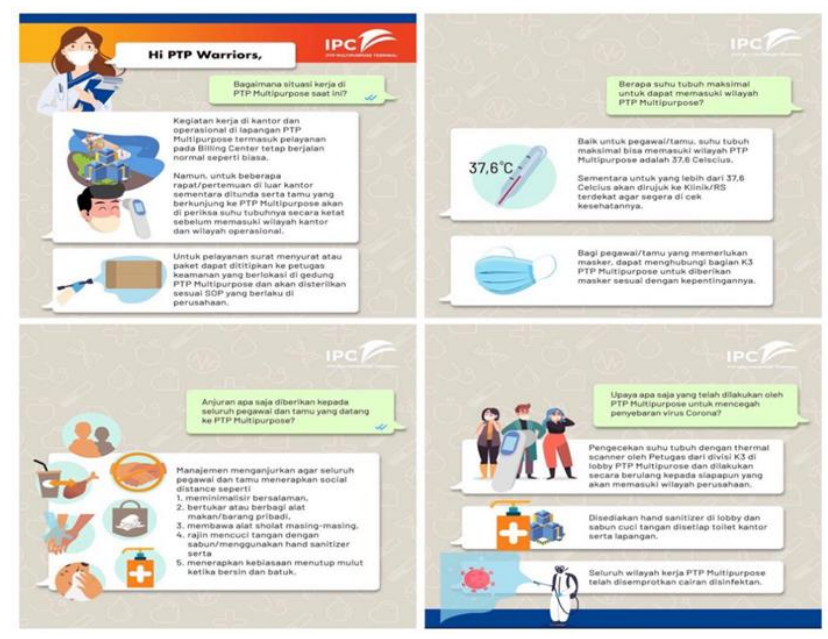

Gambar 4.7 Kampanye Tanggap Covid Sumber : Instagram @ptpmultipurpose

\section{Audience (Publik)}

PT Pelabuhan Tanjung Priok memiliki sasaran public (Audience) utama yang merupakan internal perusahaan (staff/karyawan) dan juga stakeholder (pelanggan). Melalui saluran kampanye yang dilakukan menggunakan jejaring media sosial, maka pihak manajemen perusahaan mampu mengukur tingkat partisipasi audience dalam menerima dan memberikan feedback dari pesan kampanye yang disampaikan (garmbar 2). 


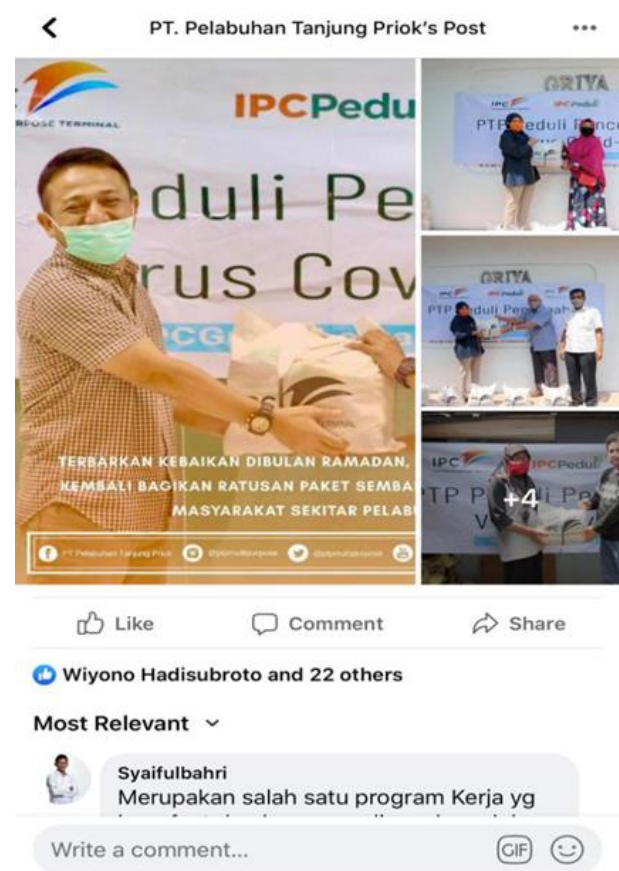

Gambar 2. Kampanye Bantuan Covid-19 Sumber : Facebook PTP Multipurpose

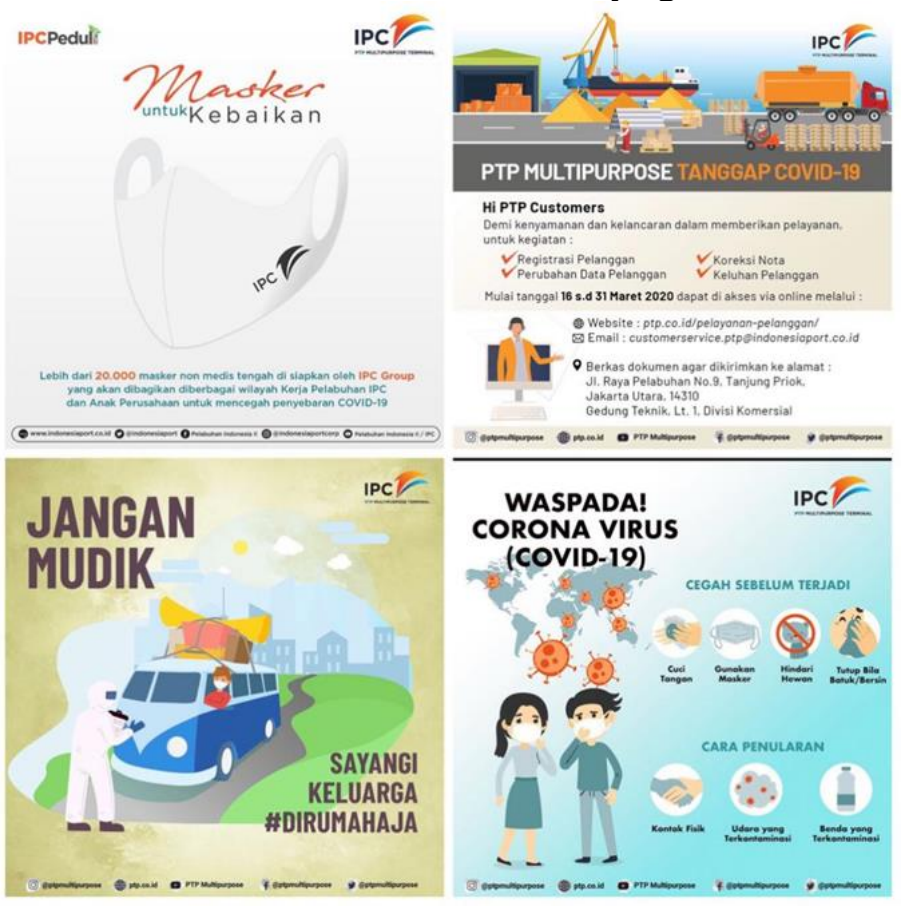

Gambar 3. Konten Kampanye Tanggap Covid-19

Sumber : Instagram @ ptpmultipurpose

\section{Strategi}

Dalam menghadapi situasi pandemi saat ini, divisi Humas PT Pelabuhan Tanjung Priok memiliki strategi dan perencanaan kampanye secara digital. program kampanye melalui

\section{Message (Pesan)}

Penyampaian pesan yang tentunya dilakukan dengan menggunakan kalimatkalimat yang dapat dimengerti oleh khalayak. Humas PT Pelabuhan Tanjung Priok mempersiapkan berbagai konten kampanye dengan menggunakan grafis, sehingga audience mampu mengerti isi pesan atau informasi tersebut tanpa membaca keterangan (caption) lebih dalam. Pemilihan bahasa yang sederhana juga menjadi pilihan Humas PT Pelabuhan Tanjung Priok dalam melakukan kampanye maupun sosialisasi di sosial media dan beberapa media lainnya. Informasi/pesan dan pengumuman yang disampaikan selalu dalam bentuk grafis, dengan maksud agar audience mampu memahami isi pesan tersebut tanpa membaca caption (keterangan). Untuk caption itu sendiri kami menggunakan bahasa yang friendly agar lebih mudah dipahami (gambar 3).

media sosial perusahaan, yaitu Facebook, Instagram, Twitter, dan Youtube. Dikarenakan kondisi pandemi saat ini yang mengharuskan kita membatasi aktivitas diluar rumah dan menjaga jarak dengan orang lain, maka kita 
memiliki strategi sosialisasi dan kampanye melalui media digital. Kami menetapkan beberapa media tersebut terutama Facebook dan Instagram untuk menjadi alternatif sosialisasi dan kampanye atas dasar media sosial tersebut menjadi platform utama saat ini yang sering digunakan masyarkat khususnya internal perusahaan sehingga dapat menjangkau banyak audience. Kita memiliki tagar atau Hashtag \#PTPWarriors untuk menjalin komunikasi kepada audience agar terkesean lebih ringan dan bersahabat ketimbang menggunakan release yang bersifat formal. Selain media sosial, kita juga memiliki media primer yang saya bahas sebelumnya yaitu E-Office dan kami melakukan sosialisasi New Normal ini khusus untuk internal perusahaan. BOD-1 dan -2 terdapat sosialisasinya, kemudian kita sebarkan melalui kanal ke para staff melalui kanal (E-Office) masing-masing (gambar 4).

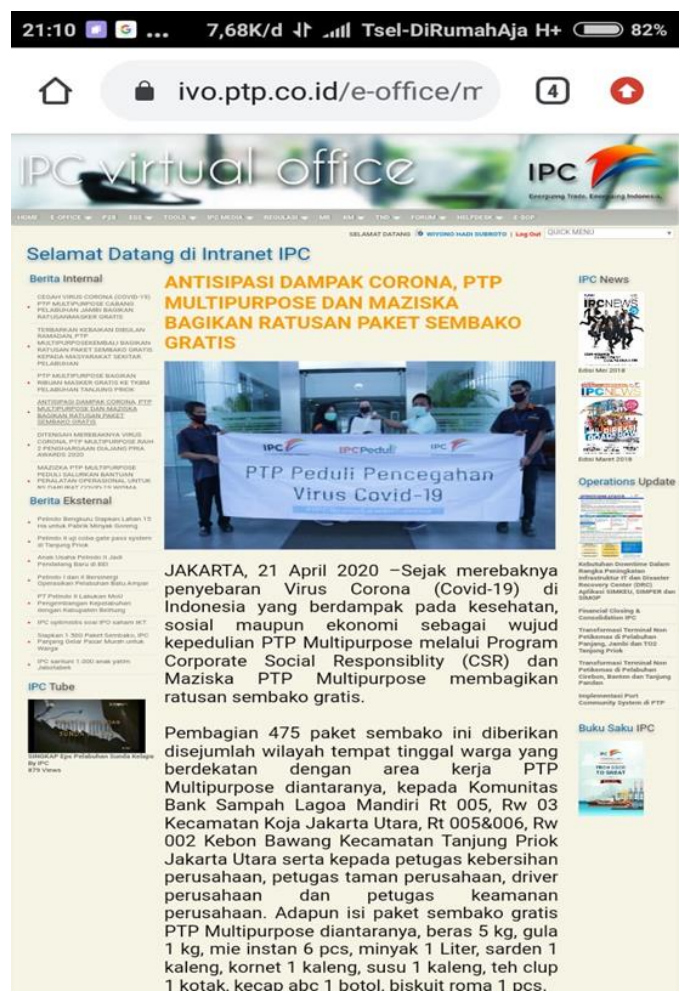

Gambar 4. E-Office PT Pelabuhan Tanjung Priok Sumber : Narasumber ke-3 (Wiyono)

Humas PT Pelabuhan Tanjung Priok memiliki strategi kampanye yang dilakukan secara digital. teori dasar untuk menganalisis strategi yang digunakan dalam objek penelitian tersebut (Setiawan \& Fithrah, 2018), hal tersebut dilaksanakan atas dasar pertimbangan keadaan dan situasi saat ini, dimana mobilitas dan aktivitas di luar rumah sedang dibatasi, sehingga audience melakukan aktivitas pekerjaan dan beberapa aktivitas lainnya secara online (digital). Penetapan media sosial tersebut sebagai domain utama penyampaian kampanye digital ini didasari atas analisa tim bahwa Facebook dan Instagram menjadi platform media sosial yang paling banyak penggunanya saat ini, sehingga lebih banyak menjangkau audience khususnya internal dan stakeholder perusahaan. Dengan menggunakan media sosial dan media primer khusus untuk internal perusahaan yaitu kanal E-Office, maka pesan dan informasi dari kampanye tersebut dapat lebih menjangkau audience. Khusus untuk kanal E-Office internal perusahaan, digunakan untuk mengakses pekerjaan dan absen online sehingga audience dapat melihat berita dan informasi seputar program kampanye yang sedang dicanangkan perusahaan di selasela pekerjaannya.

\section{Tactics (Taktik)}

Secara Deliverabillity, pihak Humas PT Pelabuhan Tanjung Priok dapat dikatakan mampu melaksanakan teknik-teknik kampanye yang didukung oleh alokasi dana perusahaan yang baik dan beberapa aspek pendukung di dalamnya. Alokasi dana perusahaan untuk mendukung pelaksanaan sosialisasi dan kampanye Tanggap Covid-19 ini sangat baik. Terhitung sejak ditetapkannya Covid-19 menjadi pandemi, maka saat itu juga direksi menginstruksikan anggaran perusahaan dialokasikan maksimal untuk Tanggap Covid19 ini. Misalnya seperti anggaran kegiatan media gathering dan sebagainya yang tidak dilakukan ketika masa pandemi ini, maka anggaran atau dana tersebut dialokasikan untuk pelaksanaan kampanye Tanggap Covid-19 dan pemberian bantuan kepada internal perusahaan dan masyarakat. 


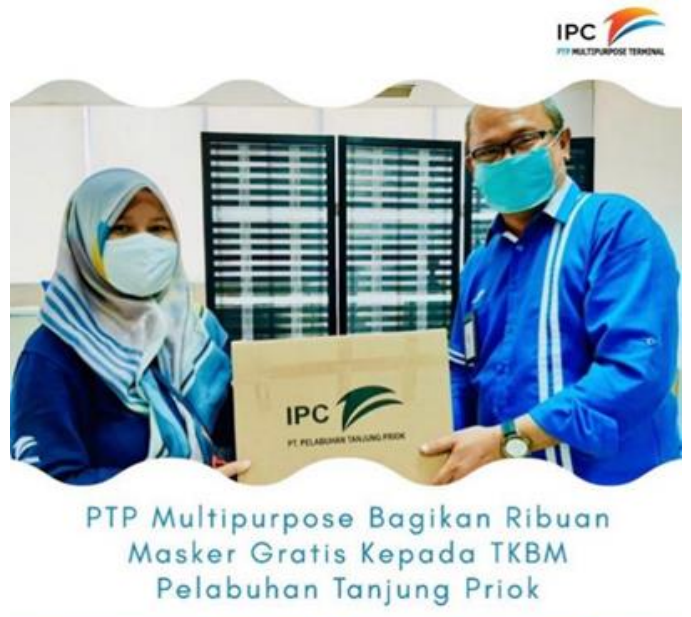

Gambar 5. Alokasi dana PTP untuk Covid-19 Sumber: Instagram @ptpmultipurpose

\section{Time Scale (Skala Waktu)}

Divisi Humas telah membuat Timeline berdasarkan informasi atau pengumuman baik dari pihak holding (IPC) maupun pemerintah yang sudah valid dan terverikasi. Langkah selanjutnya adalah berkoordinasi dengan bagian SDM guna membahas ketenaga kerjaan. Setelah itu baru kami dapat mempublikasikan program sosialisasi dan kampanye apabila halhal yang diperlukan tersebut telah dilengkapi. Kami terus berupaya untuk dapat mempublikasikan pesan kampanye ataupun sosialisasi secara aktual atau up to date, contohnya ketika ada himbauan dilarang mudik oleh pemerintah kamipun turut melakukan kampanye perihal himbauan tersebut yang sudah ditetapkan didalam Timeline kami yaitu sampai dengan H-5 sebelum lebaran. Humas PT Pelabuhan Tanjung Priok telah memiliki dan menetapkan skala waktu mereka dengan baik. Hal ini tentu berpengaruh terhadap keberhasilan program-program kampanye yang sudah berjalan dan menjadi acuan untuk program-program kampanye berikutnya.

\section{Resource (Sumber Daya)}

Dalam segi Resources atau sumber daya PT Pelabuhan Tanjung Priok telah didukung dengan Tim yang memiliki keahlian dalam bidang masing-masing. Namun dalam aspek desain grafis, PT Pelabuhan Tanjung Priok masih belum dapat menemukan sumber daya yang sesuai dengan kriteria yang dimiliki hingga perlu menggunakan jasa atau bantuan dari pihak ketiga (pihak luar) untuk membantu mengerjakan desain grafis ini. Oleh karena itu, divisi Humas PT Pelabuhan Tanjung Priok perlu didukung dengan sumber daya yang lebih segar dan memiliki kompetensi dalam bidang editing, design, dokumentasi dan lainnya yang berhubungan dengan digitalisasi.

\section{Evaluation (Evaluasi)}

Humas PT Pelabuhan Tanjung Priok bekerja sama dengan dua divisi lainnya guna mengevaluasi program-program kampanye yang telah dicanangkan oleh perusahaan serta menjadikan hal tersebut sebagai acuan untuk program-program kampanye selanjutnya. Selain itu dari segi program dan pelaksanaan teknis kampanye PT Pelabuhan Tanjung Priok ialah perlu diperhatikan kembali perihal ketepatan dan aktualisasi waktu publikasi konten kampanye.

\section{Review (Penilaian)}

Kegiatan dan program kampanye yang dilakukan oleh Humas PT Pelabuhan Tanjung Priok dapat dikategorikan berhasil dan berjalan dengan baik. Hal tersebut didukung oleh fakta dan keadaan di lapangan dimana para internal perusahaan sadar akan pencegahan serta penanggulangan virus Covid-19 dengan memperhatikan protokol kesehatan dan mentaati himbauan untuk tidak melakukan mudik di hari raya Idul Fitri tahun 2020 ini. Begitupun dari pihak stakeholder (pelanggan) yang merasa puas dengan pelayanan yang diberikan PT Pelabuhan Tanjung Priok di tengah pandemi yang sedang berlangsung saat ini. Pelanggan dimudahkan mengakses pengumuman dan informasi yang ditampilkan dalam sebuah bentuk infografis yang menarik dan juga layanan pelanggan yang koperatif dan optimal.

Dalam 10 Tahap perencanaan kampanye selanjutnya, diperlukan adanya alokasi dana yang baik dalam berjalannya 
program yang optimal karena berkaitan erat dengan taktik kampanye. PT Pelabuhan Tanjung Priok dengan sungguh-sungguh mengalokasikan dana perusahaan untuk mendukung berjalannya program-program sosialisasi dan kampanye Tanggap Covid-19.

Terkait evaluasi dan penilaian yang dikemukakan oleh DVP Corporate Communications PT Pelabuhan Tanjung Priok yaitu program yang berjalan dapat dikaterogikan berhasil dengan melakukan koordinasi dengan Tim Penangan Covid-19 sebagai bagian dari evaluasi tersebut. Namun dalam pelaksanaan kampanye digital perlu ditinjau kembali perihal efisiensi dan aktualisasi proses pembuatan konten kampanye yang masih bergantung dari pihak luar dalam hal desain.

Kampanye ini dimaksudkan agar internal staff/karyawan PT Pelabuhan Tanjung Priok memiliki pengetahuan dan kesadaran terkait Virus Covid-19 ini dan juga menginformasikan bagi stakeholder (pelanggan) bahwa kegiatan operasional dan pelayanan tetap berjalan normal dengan mengikuti aturan protokol kesehatan yang berlaku. Dan juga Humas PT Pelabuhan Tanjung Priok melakukan kampanye tersebut sesuai dengan regulasi yang telah dibuat dan langkah-langkah yang telah ditetapkan seperti yang dikutip (Olivier, 2007:2) mendefinisikan "strategi sebagai cara untuk mencapai sebuah hasil akhir, hasil akhir menyangkut tujuan dan sasaran organisasi".

Selanjutnya Teknik triangulasi sumber digunakan untuk menguji kredibilitas data dilakukan dengan cara mengecek data yang diperoleh melalui beberapa sumber. Adapun sumber yang menjadi rujukan peneliti ialah Informan Kunci Amanda Maulina sebagai DVP Corporate Communications PT Pelabuhan Tanjung Priok. Peneliti telah melakukan wawancara mendalam dan memperoleh informasi bahwa untuk melakukan kampanye sebuah program yang dibuat dan ditujukan oleh penggunanya tidak bersifat face to face, mengingat jumlah karyawan organik dan non organik di PT Pelabuhan Tanjung Priok cukup banyak maka demi keberhasilan kampanye ini Humas PT Pelabuhan Tanjung Priok menggunakan alat atau media yang menjadi saluran kampanye khususnya media elektronik atau digital.

Kampanye adalah penyampaian pesanpesan dari pengirim kepada khalayak. Pesanpesan tersebut dapat disampaikan dalam berbagai bentuk mulai dari poster, spandik, baliho, pidato, iklan hingga selebaran dan tujuan kampanye akan tercapai apabila khalayak memahami pesan-pesan yang ditujukan pada mereka (Venus, 2004:70). Dari pernyataan diatas maka dapat disimpulkan bahwa kampanye merupakan kegiatan yang dilakukan oleh perusahaan, organisasi untuk kepentingan Bersama dengan menggunakan beberapa media komunikasi dalam proses pelaksanaan kampanye tersebut.

\section{SIMPULAN}

Berdasarkan dari hasil penelitian yang dilakukan di PT Pelabuhan Tanjung Priok terkait dengan Kampanye Tanggap Covid-19 di Area Pelabuhan Tanjung Priok yang telah diuraikan pada bab IV sebelumnya, maka peneliti memiliki beberapa kesimpulan sebagai berikut :

Pertama, Dari hasil penelitian yang dilakukan di dalam 4 Steps Of Public Relations terkait dengan perencaan (planning) kampanye Tanggap Covid-19 yang diselenggarakan oleh Humas PT Pelabuhan Tanjung Priok yaitu dengan membentuk Tim Penanganan Covid-19 bersama dengan divisi K3L dan Sumber Daya Manusia (SDM). Singkatnya, divisi K3L bertugas sebagai pengamat perkembangan keadaan di lapangan yang kemudian diteruskan melalui laporan kepada divisi SDM sebagai pembuat peraturan dan pengumuman. Selanjutnya oleh divisi Humas memiliki peran dan tugas untuk menginformasikan atau mempublikasikan peraturan dan pengumuman yang telah dibuat. Dengan demikian, Humas PT Pelabuhan Tanjung Priok dapat mengevaluasi program kampanye yang sudah berjalan dan menjadikan evaluasi tersebut menjadi acuan 
dalam proses perencanaan kampanye Tanggap Covid-19 selanjutnya.

Kedua, Dalam penelitian ini juga menggunakan konsep teori 10 Stages Of Campaign Planning dalam Kampanye Tanggap Covid-19. Humas PT Pelabuhan Tanjung Priok melakukan tahapan-tahapan kampanye tersebut secara komperhensif dimulai dengan melakukan analisa situasi hingga kepada evaluasi dan penilaian. Dalam pelaksanaannya, Humas PT Pelabuhan Tanjung Priok menggunakan media digital sebagai saluran utama kampanye. Hal ini didasari atas analisa situasi pandemi yang menuntut Humas PT Pelabuhan Tanjung Priok untuk menyusun strategi kampanye yang optimal dengan menggunakan alternatif media yang ada, sehingga tidak perlu melakukan kampanye atau sosialisasi secara langsung. Oleh karena itu PT Pelabuhan Tanjung Priok menggunakan sosial media (Facebook, Instagram, Twitter, dan Yotube) dan juga media primer internal perusahaan (E-Office) sebagai saluran utama kampanye Tanggap Covid-19.

\section{DAFTAR PUSTAKA}

Amalia, N. F. (2012). Kampanye Public Relations dalam Membentuk Sikap Khalayak (Studi Pada Kampanye Stop The Trafficking Children And Young People yang Diselenggarakan oleh The Body Shop Indonesia).

Basrowi \& Suwandi. (2008). Memahami Penelitian Kualitatif. Jakarta: Rineka Cipta

Chandra, A. L. (2014). Strategi Kampanye "Breast Cancer Awareness Month. Jurnal E-Komunikasi, 2(1). http://publication.petra.ac.id/index.php/ ilmu-komunikasi/article/view/1759

Gregory, A. (2004). Perencanaan dan Manajemen Kampanye Public Relations. Terjemahan. Jakarta: Erlangga.

Gunawan, I. (2013). Metode Penelitian Kualitatif: Teori dan Praktik. Jakarta: PT. Bumi Aksara.
Hogg, M. A. (2018). Self-Uncertainty, Leadership Preference, And Communication of Social Identity. Atlantic Journal of Communication, 26(2), 111-121. https:// doi.org/10.1080/15456870.2018.14326 19

Kaligis, R. A. W., Pratiwi, A., \& Anshari, F. (2020). Analisis Pengaruh Kampanye Public Relations \#SaveGBK dan Identitas Sosial Pada Sikap Jakmania Depok. Jurnal Ilmu Komunikasi, 18(2), 154-168.

https://doi.org/10.31315/jik.v18i2.3539

Khoerunnisa, R., Abidin, Y. Z., dan Ma'arif, A. A. (2018). Aktivitas Kampanye Public Relations dalam Mensosialisasikan Internet Sehat dan Aman. Humas: Jurnal Ilmu Hubungan Masyarakat, 3(4), 79-96. https://jurnal.fdk.uinsgd.ac.id/index.ph $\mathrm{p} /$ reputation/article/view/453/96

Levinson, P. (2013). New New Media. USA: Pearson Higher Education

Ruslan, R. (2013). Kampanye Public Relations. Jakarta: PT. Raja Grafindo Persada

Setiawan, B., \& Fithrah, D. S. (2018). Kampanye Gerakan Indonesia Diet Kantong Plastik Dalam Membentuk Persepsi Masyarakat Bandung”. Jurnal Manajemen Komunikasi, 2(2), 102-117. https://doi.org/10.24198/jmk.v2i2.1290 9

Soemirat, S., \& Ardianto, E. (2012). Dasardasar public relation. PT. Remaja Rosda Karya

Sugianto, A., \& Sembiring, A. W. (2018). Kampanye Public Relations Dalam Membentuk Sikap Positif Khalayak. Jurnal Lensa Mutiara Komunikasi, 2(1), 45-60. http://e-journal.sarimutiara.ac.id/index.php/JLMI/article/vi ew/560

Venus, A. (2004). Manajemen Kampanye: Panduan Teoritis Dan Praktis Dalam Mengefektifkan Kampanye Komunikasi. Bandung: Simbiosa Rekatama Media 